\title{
KAJIAN PENGARUH PEMAHAMAN ORANGTUA TERHADAP PEMENUHAN GIZI ANAK MELALUI LUNCH BOX (BEKAL MAKANAN)
}

\author{
Fajria Umasugi ${ }^{1}$, Rosita Wondal ${ }^{2}$, Bujuna Alhahad ${ }^{3}$ \\ Universitas Khairun Ternate \\ Alamat lengkap lembaga \\ Email: fazriaumasugi25@gmail.com
}

\begin{abstract}
Abstrak:
Fase terpenting bagi pertumbuhan dan perkembangan anak adalah ketika masa bayi atau balita, karena pada masa itulah saat yang paling vital dalam membangun fondasi pertumbuhan dan perkembangan anak. Oleh karena itu di butuhkan pemahaman dalam mendidik anak usia dini. Pendidikan Anak Usia Dini merupakan wadah yang mendidik anak dalam lingkup bermain untuk menstimulasi atau merangsang pada anak usia 0-6 tahun agar ia dapat tumbuh dan berkembang secara optimal. Pada pendidikan usia dini memperbolehkan anak-anak membawa bekal makanan yang akan mereka konsumsi sebelum melakukan kegiatan karena di lembaga tidak menyediakan kantin atau warung yang menjual makanan, oleh sebab itu beberapa orang tua membawakan anak-anak makanan, namun kesadaran untuk membawakan bekal yang seimbang masih kurang. Penelitian bertujuan untuk mengetahui pemahaman orang tua tentang pemenuhan gizi anak melalui Lunch Box (Bekal Makanan). Penelitian ini menggunakan kajian pustaka, kajian pustaka dalam suatu penelitian ilmiah adalah salah satu bagian penting dari keseluruhan langkahlangkah metode penelitian. Hasil dari penelitian ini membuktikan bahwa pemahaman orang tua terhadap pemenuhan gizi pada anak usia dini melalui Luch Box (Bekal Makanan) memberikan pengaruh bagi perkembangan gizi anak.
\end{abstract}

Kata kunci: Pemahaman, Orang tua, Gizi, Bekal Makanana

Abstract

The most important phase for a child's growth and development is during infancy or toddler, because that is the most vital time in building the foundation of a child's growth and development. Therefore we need understanding in educating early childhood. Early Childhood Education is a place that educates children in the scope of play to stimulate or stimulate children aged 0-6 years so that they can grow and develop optimally. PAUD allows children to bring food supplies that they will consume before doing activities because the institute does not provide canteens or food stalls that sell food, therefore some parents bring children food, but the awareness to bring balanced supplies is still lacking. The study aims to determine the understanding of parents about the fulfillment of children's nutrition through the Lunch Box. This research uses literature study, literature study in a scientific research is one important part of the overall steps of the research method. The results of this study prove that

\footnotetext{
${ }^{1}$ Mahasiswa PG PAUD Unkhair

${ }^{2}$ Dosen PG PAUD Unkhair

${ }^{3}$ Dosen PG PAUD Unkhair
} 
parents' understanding of the fulfillment of nutrition in early childhood through Luch Box provides food for children's nutritional development.

Keywords: Comprehension, Parents, Nutrient, Lunch box

\section{A. Pendahuluan}

Fase terpenting bagi pertumbuhan dan perkembangan anak adalah ketika masa bayi atau balita, karena pada masa itulah saat yang paling vital dalam membangun fondasi pertumbuhan dan perkembangan anak. Oleh karena itu di butuhkan pemahaman dalam mendidik anak usia dini. Sebagai orang tua yang cerdas dan memahami karakteristik anak, maka diperlukan kepekaan mengenai masa penting anak, salah satunya ketika anak mengalami masa golden age. Pendidikan Anak Usia Dini merupakan wadah yang mendidik anak dalam lingkup bermain untuk menstimulasi atau merangsang pada anak usia 0-6 tahun agar ia dapat tumbuh dan berkembang secara optimal. Masalah kekurangan gizi masih tersebar luas di negara negara berkembang yang berakar dari masalah kemiskinan salahsatunya adalah Indonesia.

Hal ini sesuai dengan data yang diungkapkan oleh gizi anak pada Departemen Kesehatan Indonesia yang menyatakan bahwa Indonesia termasuk negara yang memiliki masalah gizi yang kompleks yang ditunjukkan dengan tingginya prevalensi stuting atau yang lebih dikenal sebagai balita pendek, dimana pertumbuhan berat badan dan tinggi badan kurang sesuai pada angka yang tertera pada Kartu Menuju Sehat (KMS), selain itu ada pula permasalahan mengenai prevalensi wasting atau yang lebih dikenal sebagai balita kurus, dimana sebagian besar balita memiliki jumlah berat badan yang jauh dari standar berat badan balita yang terdapat pada KMS, dan yang terakhir permasalahan gizi lebih.

Anak merupakan kelompok yang menunjukan pertumbuhan yang sangat pesat sehingga memerlukan zat gizi yang tinggi setiap kilogram berat badannya. Peran orang tua sangat penting dalam pemenuhan gizi karean dalam saat seperti ini anak sangat membutuhkan perhatian dan dukungan orang tua dalam menghadapi pertumbuhan dan perkembangan yang sangat pesat. Untuk mendapatkan gizi gizi yang baik diperlukan pengetahuan gizi yang baik dari orang tua agar dapat menyediakan menu pilihan yang seimbang (Devi, 2012).

Stunting(tubuh pendek)adalah keadaan dimana tubuh yang sangat pendek hingga melampaui defisi -2 standar deviasi (SD) dibawah median panjang atau tinggi yang menjadi referensi internasional.Ada beberapa faktor yang mempengaruhi stuntingpada anak yakni faktor langsung yaitu asupan makanan dan penyakit infeksi serta faktor tidak langsung yakni pengetahuan gizi yakni pengetahuan tentang gizi, pendidiakan orang tua, pendapatan orangtua, distribusi makanan, besar 
keluarga(Supariasa, Bakri, \& Fajar, 2002).Oleh karena itu masalah anak pendek merupakan cerminan dari keadaan sosial ekonomi masyarakat. Karena masalah gizi pendek diakibatkan oleh keadaan yang berlangsung lama, maka ciri masalah gizi yang ditunjukan oleh anak pendek adalah masalah gizi yang sifatnya kronis (Gibney dkk, 2009)

Salah satu menu makanan yang sesuai dengan gizi seimbang adalah bahan makanan yang alamiah dan segar seperti ikan, daging dan sayuran beku. Menyiapkan bekal makanan untuk anak ke sekolah ditengah waktu yang sibuk merupakan tantangan dan masalah utama bagi orang tua saat ini. Namun bisa diatasi dengan cara menghidangkan atau menyiapkan makanan siap saji yang mudah. PAUD memperbolehkan anak-anak membawa bekal makanan yang akan mereka konsumsi sebelum melakukan kegiatan karena di lembaga tidak menyediakan kantin atau warung yang menjual makanan, oleh sebab itu beberapa orang tua membawakan anak-anak makanan, ragam makanan yang dibawakan memiliki berbagai bentuk, seperti makanan ringan yang dibungkus merk tertentu dengan alasan anak sudah sarapan di rumah ada pula yang membawakan berupa nasi dan makanan berat yang bisa dikonsumsi anak selama di sekolah, namun kesadaran untuk membawakan bekal yang seimbang masih kurang, sebagian besar orang tua siswa-siswi merupakan karyawan, dosen, guru hingga pegawai negeri sipil.

Berdasarkan latar belakang masalah diatas, maka peneliti mendapatkan permasalahan masalah adalah bagaimana pemahaman orang tua tentang pemenuhan gizi anak melalui Lunch Box (Bekal Makanan). Penelitian bertujuan adalah mengetahui pemahaman orang tua tentang pemenuhan gizi anak melalui Lunch Box (Bekal Makanan). Adapun beberapa manfaat yang didapatkan dari penelitian ini dapat dilihat dari dua sisi yaitu Secara Teoritis Diharapkan dengan adanya penelitian mengenai pemahaman orang tua tentang pemenuhan gizi anak melalui Lunch Box (bekal makanan). Bisa memperluas pengetahuan mengenai bekal makanan yang sehat bagi anak-anak, sehingga ilmu mengenai kesehatan dan gizi anak bisa lebih luas lagi cangkupannya, khususnya bagi Pendidikan Guru Pendidikan anak Usia Dini. Hasil penelitian ini bisa dijadikan acuan bagi peneliti lain yang memiliki gagasan yang sama.

\section{B. Kajian Teori}

1. Orang tua

Pengertian Orang tua dalam kutipan artikel berjudul "Pengertian arti dari makna orang tua" dalam Kompasiana yang diakses pada 6 November 2016, adalah pengertian umum dari seseorang yang melahirkan kita yaitu orang tua biologis. Namun orang tua juga tidak selalu dalam pengertian yang melahirkan. Orang 
tua juga bisa didefinisikan terhadap orang yang telah memberi arti kehidupan bagi kita. Orang tua telah mengasihi, memelihara bahkan memberikan kasih sayang walau bukan mereka yang melahirkan kita. Menurut Johnson dan Leny (2010:5) keluarga adalah suatu sistem yang mempunyai anggota yaitu, ayah, ibu dan anak atau semua individu yang tinggal di dalam rumah tangga tersebut. Anggota keluarga saling berinteraksi, interlasi dan interpendensi untuk mencapai tujuan bersama. Masyarakat menyakini bahwa keluarga sehat akan mempunyai anggota yang sehat pula sehingga mewujudkan masyarakat sehat.

Keluarga merupakan pusat pendidikan yang pertama dan terpenting karena sejak kemunculan adab kemanusiaan sampai sekarang, keluarga selalu berpengaruh besar terhadap perkembangan anak manusia. Peranan orang tua bagi pendidikan anak ialah memberi dasar pendidikan, sikap dan keterampilan dasar, seperti pendidikan agama, budi pekerti, sopan santun, estetika, kasih sayang dan rasa aman. Pentingnya peran orang tua dalam pendidikan anak telah disadari oleh banyak pihak, karena akan member efek peningkatan prestasi belajar, perbaikan sikap, stabilitas sosioemosional, kedisiplinan serta aspirasi anak untuk belajar (Noor, 2009:19).

Menurut Setiono (2011:24) bahwa keluarga adalah orang yang ada hubungan darah atau perkawinan. Orang-orang yang termasuk keluarga adalah ibu, bapak, dan anak-anaknya. Ini disebut keluarga batih (nuclear family). Keluarga yang diperluas (extended family) mencakup semua orang dari satu keturunan kakek dan nenek yang sama, termasuk keturunan suami dan istri. Keluarga mempunyai fungsi untuk berkembang biak, mensosialisasi atau mendidik anak, menolong serta melindungi yang lemah, khususnya orang tua yang telah lanjut usia.

Dari beberapa penjelasan mengenai pengertian orang tua, maka dapat disimpulkan bahwa orang tua merupakan bagian dari keluarga yang paling dasar bagi anak dalam kehidupan mereka. Orang tua terdiri dari ayah, ibu dan anak yang didasari oleh sebuah hubungan darah atau perkawinan, dengan keterlibatan orang tua dalam kehidupan anak, diharapkan mereka menjadi lebih terarah agar bisa bertahan hidup ketika dewasa.

2. Pemahaman

Pemahaman adalah kesanggupan memahami setingkat lebih tinggi daripada ilmu pengetahuan. Dalam memahami dan mempelajari suatu hal tidak berarti manusia melupakan peran dari pengetahuan, namun melalui ilmu pengetahuan kita akan di perkenalkan dan akan mengetahui secara mendalam agar lebih 
memahami dan mengetahui (Sudjana, 2009: 24). Terdapat tiga tingkat pemahaman menurut Sudjana (2014: 24) dalam tingkat yang pertama yaitu, pemahaman terjemahan, mulai dari mennerjemahkan arti dalam pemahaman yang sebenarnya. Pada tingkat kedua adalah pemahaman penafsiran yaitu menghubungkan bagian-bagian dipelajari sebelumnya dengan hal-hal yang baru, atau menghubungkan dengan beberapa bagian dari grafik melalui kejadian yang sudah ada. Sedangkan yang ketiga atau tingkat tertinggi adalah pemahaman ekstrapolasi yaitu seseorang diharapkan mampu melihat di balik pengetahuan seseorang sehingga dapat membuat ramalan tentang konsekuensi atau akibat, dan dapat memperluas anggapan mengenai suatu hal dalam arti waktu, dimensi, kasus ataupun masalahnya.

Bedasarkan pendapat yang telah dikemukakan diatas, dapat disimpulkan bahwa pemahaman adalah suatu tindakan untuk belajar lebih mendalam mengenai suatu hal yang berhubungan dengan ilmu pengetahuan. Pemahaman lebih dari sekedar mengerti, oleh sebab itu pemahaman mengenai gizi, artinya memahami secara mendalam, detail dan juga menyeluruh mengenai gizi yang terkandung. Sehingga pemenuhan gizi untuk kebutuhan sehari-hari menjadi terpenuhi.

3. Gizi

Gizi merupakan salah satu kebutuhan yang didapatkan manusia melalui makanan yang ia konsumsi sehari-hari, jumlah yang dibutuhkan setiap individu juga berbeda, baik anak-anak ataupun orang dewasa. Menurut Almatsier (2010: 294) pedoman umum gizi seimbang adalah pedoman yang disusun dalam rangka memenuhi salah satu rekomendasi Konfrensi Gizi Internasional untuk mencapai dan memelihara kesehatan dan kesejahteraan gizi semua penduduk yang merupakan prasyarat untuk pembangunan sumber daya manusia.

Dalam pedoman umum gizi seimbang susunan makanan yang dianjurkan adalah yang menjamin keseimbangan zat-zat gizi. Pengelompokan bahan makanan disederhanakan, yaitu didasarkan pada tiga fungsi utama zat gizi, yaitu sebagai sumber energi, sumber zat pembangun dan sumber zat pengatur. Ketiga golongan bahan ini digambarkan dalam bentuk kerucut dengan urutan-urutan menurut banyaknya digunakan dalam hidangan sehari-hari.

Suatu menu adalah susunan hidangan sekali makan yang secara keseluruhan harmonis dan saling melengkapi untuk kebutuhan makan seseorang. Dalam hal kesehatan, seringkali digunakan istilah menu adekuat yaitu menu yang mengandung semua golongan bahan makanan yang dibutuhkan dengan 
memperhatikan kseimbangan unsur-unsur gizi yang terkandung di dalamnya. Konsep menu adekuat menekankan unsur gizi yang dibutuhkan oleh tubuh, yaitu pemberi tenaga atau energi, penyokong pertumbuhan, pembangun dan pemelihara jaringan tubuh serta pengatur metabolisme (Santoso,2013: 123).

Menurut Hidayat (2011:41) nutrisi makanan sangat bermanfaat bagi tubuh dalam membantu proses pertumbuhan dan perkembangan anak serta mencegah terjadinya penyakit akibat kurang nutrisi pada tubuh seperti kekurangan energi dan protein, anemia, defisiensi yodium, defisiensi seng, defisiensi vitamin A yang menghambat proses tumbuh kembang anak. Sumber tenaga nutrisi dapat diperoleh dari karbohidrat sebesar 50-55\%, dari lemak 30$35 \%$ dan protein sebanyak 15\%. Pemenuhan nutrisi pada anak harus seimbang dan mengandung semua zat gizi yang diperlukan tubuh. Menu makanan sehat memiliki syarat, menurut Santoso dalam buku Kesehatan dan Gizi (2013:123) yaitu :

a. Mengandung makanan yang memuaskan selera makan serta memberikan rasa kenyang.

b. Mengandung zat gizi yang dibutuhkan untuk berada dalam kondisi tetap sehat serta dapat melakukan kegiatan sehari-hari.

c. Memenuhi nilai-nilai sosial budaya yaitu kebiasaan, pantangan dan sebagainya dari masyarakat yang mengkonsumsinya.

d. Biaya terjangkau bagi konsumennya.

Menurut Kamus Besar Bahasa Indonesia (2012) bekal merupakan sesuatu yang disediakan (seperti makanan, uang) yang digunakan untuk perjalanan atau sesuatu yang digunakan kelak apabila perlu. Sedangkan menurut Almatsier (2010) makanan adalah bahan selain obat yang mengandung zat-zat gizi dan atau unsurunsur ikatan yang dapat diubah menjadi zat gizi oleh tubuh, yang berguna bila dimasukan ke dalam tubuh. Sama dengan pendapat dari Sibuea (2006) bahwa makanan adalah kebutuhan pokok manusia yang dibutuhkan setiap saat dan memerlukan pengelolaan yang baik dan benar agar bermanfaat bagi tubuh. Batasan makanan tersebut tidak termasuk air, obat-obatan dan substansi-substansi yang diperlukan untuk tujuan pengobatan.

Menurut Muaris (2006:6) menyatakan bahwa membiasakan membawa bekal makanan ke sekolah merupakan gaya hidup yang sebaiknya diberikan kepada anak oleh setiap orangtua. Manfaat yang diberikan adalah mencegah anak untuk mengkonsumsi makanan yang tidak sehat, dan jajan sembarangan. Sejalan dengan Muaris, manfaat membawa bekal menurut Olvista (2013) adalah kebiasaan baik bagi anak. Membawa bekal memastikan bahwa anak akan mendapatkan makanan yang cukup dan menghindari anak merasa 
kelaparan yang dapat mempengaruhi kesehatan maupun konsentrasi belajar.

\section{Metode Penelitian}

Penelitian ini menggunakan kajian pustaka, kajian pustaka dalam suatu penelitian ilmiah adalah salah satu bagian penting dari keseluruhan langkah-langkah metode penelitian. Cooper dalam Creswell (2010) mengemukakan bahwa kajian pustaka memiliki beberapa tujuan yakni; menginformasikan kepada pembaca hasilhasil penelitian lain yang berkaitan erat dengan penelitian yang dilakukan saat itu, menghubungkan penelitian dengan literatur-literatur yang ada, dan mengisi celah-celah dalam penelitian-penelitian sebelumnya. Geoffrey dan Airasian mengemukakan bahwa tujuan utama kajian pustaka adalah untuk menentukan apa yang telah dilakukan orang yang berhubungan dengan topik penelitian yang akan dilakukan. Dengan mengkaji penelitian sebelumnya, dapat memberikan alasan untuk hipotesis penelitian, sekaligus menjadi indikasi pembenaran pentingnya penelitian yang akan dilakukan. Lebih lanjut Anderson mengemukakan bahwa kajian pustaka dimaksudkan untuk meringkas, menganalisis, dan menafsirkan konsep dan teori yang berkaitan dengan sebuah proyek penelitian.

\section{Pembahasan}

Hasil dari penelitian ini membuktikan bahwa pemahaman orang tua terhadap pemenuhan gizi pada anak usia dini melalui Luch Box (Bekal Makanan) memberikan pengaruh bagi perkembangan gizi anak. Pada salah satu penelitian oleh Astrianti (2019) dari 52 anak yang membawa bekal makanan terdapat 38 anak yang memiliki status gizi normal. Hal ini menunjukkan bahwa komposisi tubuh anak berdasarkan tinggi dan berat badannya adalah normal. Anak sekolah telah memiliki kebiasaan membawa bekal makanan ke sekolah namun tidak sesuai dengan pedoman gizi seimbang dan kualitas zat gizinya masih kurang dari AKG yang dianjurkan pada anak usia sekolah. Anak yang lebih banyak memperoleh $\geq 33 \%$ sumbangan dari bekal makanan yang mengandung energi, protein, vitamin $\mathrm{C}$, vitamin $\mathrm{E}$ dan zat besi. Sedangkan anak yang lebih banyak memperoleh $<33 \%$ sumbangan dari bekal makanan yang mengandung lemak, serat, vitamin A, vitamin D dan kalsium. Terdapat hubungan antara kecukupan gizi anak yang membawa bekal makanan baik energi, protein, dan lemak dengan status gizi anak di SD Negeri no. 060890 Kecamatan Medan Polonia dimana pvalue $\leq 0,05$. Serta tidak terdapat hubungan antara kecukupan gizi anak yang membawa bekal makanan baik serat, vitamin A, vitamin C, vitamin D, vitamin E, kalsium dan zat besi dengan status gizi anak di SD Negeri no. 060890 Kecamatan Medan Polonia dimana pvalue >0,05. 
Menurut penelitian Agustina (2015) tentang asupan zat gizi mikro dan serat menurut status gizi anak usia 6-12 tahun di Pulau Sulawesi menjelaskan bahwa rata-rata asupan serat pada anak usia 6-12 tahun 3,91 gr/hari, standar deviasi 2,04 gr. Padahal asupan serat yang tinggi dapat menurunkan risiko obesitas, diabetes dan sembelit serta menurunkan beberapa penyakit kronis lainnya khususnya pada anak yang memberikan dampak di usia dewasa. Dalam penelitian Agustina, dengan menggunakan uji one-way anova menghasilkan $p>0,05$ yang artinya tidak terdapat perbedaan asupan serat terhadap status gizi di Pulau Sulawesi. Penelitian lain yang dilakukan oleh Rahayuningtiyas (2012) menjelaskan bahwa tidak ada hubungan yang signifikan antara asupan serat dengan status gizi lebih.

Berdasarkan pengalaman dan penelitian, diperoleh bahwa perilaku yang didasari oleh pengetahuan lebih langgeng daripada perilaku yang tidak didasari pengetahuan (Maulana, 2009). Faktor pengetahuan mempengaruhi keseriusan yang dirasakan orang risiko tinggi terhadap status gizi anak. Orang tua yang anaknya berisiko tinggi yang memiliki pengetahuan tinggi tentang permasalahan status gizi akan merasakan keseriusan yang sangat kuat terhadap status gizi anak sehingga dengan keseriusan yang dirasakannya, orang tua anak berisiko tinggi tersebut akan terdorong untuk melakukan kontrol anaknya di Puskesmas.

Penelitian Muhammad Kasim dkk (2017) mengungkapkan bahwa terdapat Kendala yang di Hadapi. Adapun kendala-kendala yang dihadapi dalam penerapan bekal makanan sehat adalah sebagai berikut :

1. Adanya orang tua yang tidak mau mematuhi aturan tentang bekal anak di sekolah dengan alasan anaknya yang meminta

2. Banyaknya iklan di TV yang mempromosikan berbagai jenis makanan yang menarik minat anak-anak untuk mencobanya, walaupun makanan tersebut tidak memberikan manfaat kepada anak itu sendiri.

3. Kurangnya kontrol atau pengawasan dari orang tua dirumah terlebih orang tua yang semua bekerja, anak bebas jajan yang belum tentu bagus untuknya,

4. Kebiasaan orang tua yang memberikan uang jajan kepada anaknya tanpa mengontrol penggunaannya.

5. Banyak warung/penjual makanan disekitar sekolah yang selalu menarik minat anak untuk jajan

6. Masih adanya orang tua yang malas ikut parenting yang dilaksanakan disekolah dengan alasan kesibukan pekerjaan.

Muhammad Kasim dkk (2017) juga menjelaskan bahwa terdapat Faktor-Faktor Pendukung Dalam penerapan Bekal Makanan Sehat, beberapa hal dibawah ini adalah merupakan faktor pendukung antara 
lain : Anak yang mudah diberi pengertian dan arahan oleh guru disekolah, Guru memilki kemauan keras untuk mengontrol, mengevaluasi bekal anak setiap hari disekolah. Guru memasukkan dalam program pembelajaran seperti dalam tema Kebutuhanku, sub tema makanan dan Minuman, guru memperkenalkan jenis-jenis makanan dan gizi serta manfaatnya bagi tubuh anak.

Interaksi antara ibu dengan anak merupakan interaksi pertama kali dan utama yang mempunyai nilai penting bagi proses kehidupan selanjutnya. Sunaryo dalam Istiany dan Rusilanti (2013) menyatakan bahwa perkembangan anak balita sangat dipengaruhi oleh ibu, karena ibu-lah yang paling dominan dalam pengambilan keputusan pola pengasuhan kepada anak. Begitupun dengan pemberian makanan dan nutrisi bagi anak sangat dipengaruhi oleh ibu sebagai orang yang berperan penting dalam menyiapkan dan menyediakan makan bagi anak serta pengasuhannya. Penyiapan dan penyediaan makanan bagi anak yang berguna untuk membangun pola makan sehat ini perlu ibu ketahui dan dipahami oleh para ibu karena menurut penelitian Birch et al., (2007), "Parents influence children's eating behavior in a variety of ways: parents actively make food choice for the family, serve as models for dietary choice and patterns, ad use feeding practices to reinforce the development of eating patterns and behaviors that they deem appropriate".

Orang tua pada dasarnya berkewajiban untuk menyajikan kondisi yang menguntungkan bagi pertumbuhan dan perkembangan bagi anaknya. Begitu juga dalam hal pemenuhan kebutuhan jasmani, dalam hal ini berkaitan dengan pemenuhan gizi pada makanan yang dikonsumsi anak sehari-hari. Mengenalkan buah dan sayuran serta makanan bergizi lainnya sejak anak mulai mengenal makanan padat yaitu di usia 6 bulan. Hal ini akan membantu anak untuk menyukai buah dan sayuran dan makanan bergizi lainnya di usia batita dan balita nya yang merupakan masa pilih-pilih makanan.

Berdasarkan hasil diskusi dengan orang tua tentang masalah yang dihadapi orang tua dalam membangun pola makan sehat, ditemukan beberapa masalah yang datang dari anak yaitu susah makan, pilih-pilih makanan (beragam mulai dari yang tidak suka ikan, daging, sayuran, nasi, buah), konsumsi mie instan yang sering, dan jajan yang tidak bisa dibatasi. Sedangkan masalah yang berasal dari diri orang tua adalah tidak sabar ketika melihat anak susah makan, mudah jengkel, malas untuk memasak ketika anak tidak mau makan, kurang memberi tahu anak tentang guna makanan ataupun bahaya makanan, serta penggunaan fetcin/masako yang harus selalu digunakan. Masa kanakkanak sering dikeluhkan para orang tua sebagai masa sulit untuk makan. Anak lebih memilih makanan jajanan dibandingkan dengan makanan 
yang disajikan dan disediakan oleh ibunya. Sehingga akhirnya orang tua membiarkan anaknya membeli makanan jajanan yang lebih disukai anak. ermasalahan ini menjadi penyebab permasalahan gizi anak.

Anak usia batita hingga balita rata-rata mulai pilih-pilih makanan atau dikenal dengan istilah "picky eater" yaitu keadaan anak yang pilihpilih makanan, dan biasanya tidak menyukai sayuran dan buah-buahan, mereka lebih menyukai makanan instan dan makanan siap saji. "Picky eaters are characterized as consistently being unwilling to try new foods or having strong opinions on food preferences, preparation methods, and choice of food group"(Carrut BR, et al., 2004 and Carrut BR, et al., 1998 dalam Shim, et al., 2011: 1363). Orang tua perlu berhati-hati dengan pilihan anak, jangan sampai mengabaikan asupan gizi yang sedang dibutuhkan dalam masa pertumbuhannya.

Para ahli berbeda pendapat tentang faktor yang menyebabkan perilaku picky eaters. Penelitian yang dilakukan Shim, et al., (2011) menunjukkan bahwa perilaku ini berawal dari praktek pemberian makanan tambahan yang tidak tepat baik dari sisi waktu maupun jenis makanan tambahan. Menurut penelitian ini, pemberian makanan tambahan yang diberikan sebelum bayi berusia 6 bulan akan mengakibatkan resiko picky eaters pada usia prasekolah. Pemberian makanan tambahan pada usia 6 bulan dan dengan mengenalkan beragam makanan akan meningkatkan perilaku makan sehat pada usia prasekolah. "Early exposure to fruit and vegetables during infancy may promote higher consumption in later childhood" (Cooke L, et al., 2003 dan Skinner JD, et. al., 2002 dalam Shim, et al., 2011: 1363). Begitu pun dengan makanan bergizi lainnya ketika dikenalkan pada anak sedini mungkin pada usia anak sudah diperbolehkan mendapat makanan tambahan tentunya akan meningkatkan kemungkinan penerimaan anak terhadap makanan tersebut. Hal ini sejalan dengan pendapat Shim, et al., (2011: 1363): "Food preferences is developed not only from genetically determined predispositions, but can also be modified by experiences, such as repeated exposure, feeding context, and social and physiological consequences".

Berbagai penyebab anak memiliki kebiasaan jajan selain dari rendahnya aturan yang diterapkan oleh orangtua, juga bisa disebabkan karena pada masa anak pilih-pilih makanan, anak tidak mendapatkan alternatif makanan yang menarik minat anak untuk mengonsumsinya sehingga rasa lapar anak tercukupi dari makanan jajanan yang rasanya lebih gurih dan lebih disukai anak-anak. Contento et al., (dalam Brown dan Jane, 2004: 262) menemukan hubungan antara motivasi ibu tentang kesehatan dengan kualitas asupan gizi anak. Ibu yang memiliki motivasi tinggi akan memberikan asupan gizi yang baik pada makanan anak. Aturan orang tua sebagai kontrol bagi konsumsi anak dapat dilakukan 
dalam bentuk pemberian hadiah jika anak mengonsumsi makanan bergizi, akan tetapi hadiahnya pun harus makanan yang bergizi pula.

Kebiasaan jajan dapat pula diminimalisir dengan pemberian makanan camilan yang sehat, bervariasi dan menarik bagi anak. Makanan camilan yang sehat ini akan lebih baik disediakan oleh orang tua di rumah, karena terjamin keamanan dan kehigienisan makanan tersebut. Dengan memberikan makanan camilan, maka anak bisa mendapatkan tambahan kalori diluar makanan pokok.

Pengulangan yang dilakukan dalam menyodorkan makanan sehat dan bergizi perlu dilakukan secara konsisten dan kontinyu. Ketahanan dan kesabaran serta pengetahuan dan motivasi orang tua sangat mempengaruhi proses ini. Seberapa besar ketahanan dan kesabaran orang tua dalam menyodorkan dan membiasakan makan makanan yang sehat dan bergizi pada anak yang akan menentukan keberhasilan proses pembentukan pola makan sehat dalam lingkungan terkecil anak yaitu keluarga. Pengetahuan dan motiavasi orang tua dalam memberikan makanan bergizi dan membiasakannya akan menentukan keberhasilan pembentukan pola makan sehat bagi anak.

Praktek pemberian makan pada anak selain untuk memenuhi kebutuhan gizi demi kelangsungan hidup, pemulihan kesehatan, pertumbuhan dan perkembangan, juga untuk mendidik anak supaya dapat menerima, menyukai, memilih makanan yang baik dan membina kebiasaan makan yang baik. Hal-hal yang perlu diperhatikan dalam praktek pemberian makan anak, yaitu:

1. menyesuaikan metode pemberian makan dengan kemampuan psikomotor anak;

2. pemberian makan yang responsif, termasuk dorongan untuk makan, memperhatikan nafsu makan anak, waktu pemberian, kontrol terhadap makanan antara anak dan pemberi makan, dan hubungan yang baik dengan anak selama memberi makan;

3. situasi pemberian makan, termasuk bebas dari gangguan, waktu pemberian makan yang tertentu dan teratur, perhatian dan perlindungan selama makan (Istiany dan Rusilanti, 2013).

Berdasarkan penelitian yang telah dilakukan di TK Malaekat Pelindung Manado mengenai hubungan pengetahuan orang tua tentang gizi dengan stuntingpada anak usia 4-5 tahun, maka kasimpulan dalam penelitian ini sebagai berikut :

1. Kejadian stunting pada anak usia 4-5 tahun di TK Malaekat Pelindung Manado yang diukur berdasarkan indeks tinggi badan menurut umur (TB/U) pada umumnya tinggi badan anak berada pada batas normal. 
2. Pengetahuan orang tua tentang gizi di TK Malaekat Pelindung Manado sebagian besar dalam keadaan baik3.Ada hubungan pengetahuan orang tua tentang gizi dengan stuntingpada anak usia 4-5 tahun di TK Malaekat Pelindung Manado ( $p=0,000)$.

Dari data yang diperoleh dari penelitian menunjukan bahwa dari 30 anak, 24 diantaranya memiliki tinggi badan (TB/U) normal (96\%) disertai dengan pengetahuan orang tua tentang gizi yang baik, ada 1 anak yang memiliki tinggi badan normal (TB/U) tetapi memliki pengetahuan orang tua tentang gizi yang tidak baik (4\%), sedangkan 5 anak dengan stuntingmemiliki orang tua dengan pengetahuan tentang gizi yang tidak baik (100\%). Untuk kejadian stunting pada anak dimana dari 30 sampel penelitian di dapatkan kejadian stuntingsebanyak 6 orang. Hal ini terjadi mengingat pertumbuhan tinggi badan lebih lambat dan tidak mungkin dapat turun, maka stunting yang didapat menggunakan indeks antopometri (TB/U) lebih menggambarkan status gizi masa lampau. Selain itu indeks (TB/U) juga memiliki kelebihan dan kekurangan.Faktor yang mempengaruhi stuntingterbagi menjadi 2 yaitu faktor langsung dan tidak langsung. Faktor langsung yakni asupan makanan dan infksi sedangkan faktor tidak langsung yakni pengetahuan tentang gizi, pendidiakan orangtua, pendapatan orangtua, distribusi makanan, besar keluarga(Supariasa, Bakri, \& Fajar, 2002).Dalam penelitian ini pengetahuan orang tua juga secara keseluruhan baik yang berjumlah 25 orang (83.3\%), dan 5 orang tua lainnya memiliki pengetahuan yang tidak baik (16.7\%).

Pengetahuan tentang gizi pada orang tua dipengaruhi oleh beberapa faktor yaitu diantaranya adalah umur diamana semakin tua umur sesorang maka proses perkembangan mentalnya menjadi baik, intelegensi atau kemampuan untuk belajar dan berpikir abstrak guna, menyesuaikan diri dalam situasi baru, kemudian lingkungan dimana seseorang dapat mempelajari hal-hal baik juga buruk tergantung pada sifat kelompoknya, budaya yang memegang peran penting dalam pengetahuan, pendidikan merupakan hal yang mendasar untuk mengembangkan pengetahuan, dan pengalaman yang merupakanguru terbaik dalam mengasah pengetahuan (Notoatmodjo, 2010).

Stunting(tubuh pendek)adalah keadaan dimana tubuh yang sangat pendek hingga melampaui defisi -2 standar deviasi (SD) dibawah median panjang atau tinggi yang menjadi referensi internasional.Ada beberapa faktor yang mempengaruhi stuntingpada anak yakni faktor langsung yaitu asupan makanan dan penyakit infeksi serta faktor tidak langsung yakni pengetahuan gizi yakni pengetahuan tentang gizi, pendidiakan orang tua, pendapatan orangtua, distribusi makanan, besar keluarga(Supariasa, Bakri, \& Fajar, 2002).Oleh karena itu masalah anak pendek merupakan cerminan dari keadaan sosial ekonomi masyarakat. Karena masalah gizi pendek diakibatkan oleh keadaan yang berlangsung 
lama, maka ciri masalah gizi yang ditunjukan oleh anak pendek adalah masalah gizi yang sifatnya kronis (Gibney dkk, 2009).

Dari data Riset Kesehatan Dasar (Riskesdas) pada tahun 2013 diketahui bahwa prevalensi kejadian stuntingsecara nasional adalah $37,2 \%$, dimana terdiri dari 18,0 \% sangat pendek dan 19,2\% pendek, yang berarti telah terjadi peningkatan sebanyak $1,6 \%$ pada tahun 2010 (35,6 \%) dan tahun 2007 (36,8 \%). Prevalensi stunting(TB/U) lebih tinggidibandingkan dengan prevalensi kejadian underweightatau gizi buruk (BB/U) (19,6 \%) dan prevalensi kejadian wastingatau kurus (BB/TB) (5,3 \%). Pada anak balita di Indonesia ( Badan Pengembangan \& Penelitian Kesehatan, 2013).

Pada salah satu penelitian tentang program pendidikan gizi dalam membangun pola makan sehat anak usia dini di PAUD Kenanga disimpulkan dalam paparan sebagai berikut:

1. Pola makan sehat anak usiadini sangat bergantung pada peran orang dewasa disekitarnya. Keluarga terutama ibu sebagai lingkungan terdekat anak merupakan komponen yang paling utama dalam menyediakan dan memotivasi anak terkait makan sehat. Upaya membangun pola makan sehat anak usia dini dapat dilakukan antara orang tua terutama ibu.

2. Program pendidikan gizi dirancang oleh peneliti, guru dan orang tua. Penelitian ini menghasilkan program yang sesuai dengan kondisi di PAUD Kenanga. Program untuk orang tua dengan fokus pada penguatan dan penambahan wawasan ibu tentang pola makan sehat, upaya membentuk pola yang sehat untuk anak, kiat-kiat memotivasi anak yang susah makan, praktek menyusun menu yang baik, memilih dan menyiapkan camilan sehat, merencanakan apa yang akan anak makan dalam satu hari, memilih jajanan sehat dan kiat membatasi jajan anak.

Penelitian ini memperoleh data tentang pola asuh orang diketahui $83.5 \%$ orang tua mengasuh balitanya positif (asupan nutrisi adekuat), dan $16.5 \%$ orang tua mengasuh balitanya negatif (asupan nutrisi tidak adekuat). Pola asuh menyangkut asupan gizi anak selama dalam kandungan dan sesudahnya. Pola asuh positif (asupan nutrisi adekuat) juga dipengaruhi oleh beberapa faktor (Sotjiningsih, 2003) diantaranya: Pendidikan responden 57.8\% responden pendidikan SMA.

Pendidikan merupakan salah satu upaya dalam peningkatan pendidikan formal maupun nonformal. Pendidikan nonformal diantaranya dengan memberikan penyuluhan untuk meningkatkan pemahaman orang tua dalam mengasuh balitanya sehingga orang tua dalam mengasuh balitanya positif (asupan nutrisi adekuat). Dengan pola asuh yang baik maka kebutuhan asupan nutrisi balita akan dapat dipenuhi sehingga asupan nutrisi yang diberikan dapat dipergunakan 
sebagai bahan energi yang dapat digunakan untuk beraktivitas. Dari hasil penelitian diketahui bahwa status gizi balita $82.6 \%$ balita dengan kondisi status gizi baik. Status gizi merupakan keadaan keseimbangan antara asupan dan kebutuhan akan zat gizi. Status gizi baik atau optimal adalah akibat dari baiknya asupan nutrisi bagi balitanya (Poedyasmoro, 2005). Konsumsi makanan yang mengandung nutrisi sangat berperan dalam menentukan kondisi asupan gizi balita.

Kondisi tubuh yang kurang mendapat asupan nutrisi maka akan terjadi kesalahan akibat gizi diantaranya dalam hal memilihkan makanan. Banyak orang tua yang kurang mengerti bagaimana makanan yang benar - benar mengandung nutrisi. Anak diberi berbagai makanan yang orang tua tidak mengerti apa saja yang terkandung dalam makanan tersebut. Apakah makanan itu benar-benar mengandung nutrisi yang baik dan dapat meningkatkan status gizi balitanya. Balita yang berstatus gizi baik akan mengalami Peningkatan berat badan tiap bulannya, untuk mengetahuinya dapat diukur dengan timbangan berat badan. Status gizi diklasifikasikan dalam beberapa status gizi diantaranya status gizi baik, lebih, kurang dan buruk. Untuk menentukan bagaimana status gizinya diantaranya dilihat dari berat badan dibanding usia, tinggi badan dibanding usia, berat badan dibanding tinggi badan, dengan menggunakan timbangan berat badan yang tetap.

Hasil penelitian ini juga didukung oleh Tovar, et al. (2012) Feeding styles and child weight status among recent immigrant motherchild dyadsmenunjukkan hasil bahwa gaya hidup dalam pengasuhan secara langsung oleh orang tua khususnya ibu akan mempengaruhi berat badan anak (status gizi). Hasil ini menunjukkan bahwa pendampingan orang tua bagi anak sangat penting karena dapat menentukan status gizi untuk mendapatkan pemenuhan gizi sesuai dengan pertumbuhan dan perkembangan masing - masing anak. Dari penelitian ini dapar disimpulkan bahwa terdapat hubungan antara pola asuh orang tua dengan status gizi balita.

\section{E. Kesimpulan}

Berdasarkan kajian literature maka dapat disimpulkan bahwa pemahaman orang tua terhadap pemenuhan gizi anak sangat menentukan berbagai anak perkembangan kedepan. Anak yang berasal dari keluarga yang paham betul tentang pemahaman gizi pada anak akan memiliki status gizi yang baik. 


\section{DAFTAR PUSTAKA}

Almatsier, S.2011.Gizi Seimbang Dalam Daur Kehidupan. PT Gramedia Pustaka Utama.Jakarta.

Adriyana. (2013). Empat Pilar Gizi Seimbang sebagai Media Pendidikan Gizi di Indonesia. [Online]. Available at: http://sisi.blogspot.com/2013/05/empat-pilar.html?m=1

Birch, L., Jenifer, S.S., Alison, V. 2007. Influences on the Development of Children's Eating Behaviours:

Creswell John W., 2010, Research Design: Qualitative, Quantitative, and Mixed Methods Approaches, 3th, terjemahan Achmad Fawaid, Yogyakarta

Devi, N. (2012). Gizi Anak Sekolah. Jakarta: Buku Kompas.

Gibney, M., Margets, B., Kearney J., Arab L . (2009). Ilmu Gizi Kesehatan Masyarakat. Jakarta: EGC.

Hidayat, A. A. (2011). Ilmu Kesehatan Anak untuk Pendidikan Kebidanan. Jakarta: Salemba

Istiany, A.dan Rusilanti. 2013. Gizi Terapan. Bandung: Penerbit PT Remaja Rosdakarya.

Jhonson, L., \& Leny, R. (2010). Keperawatan Keluarga. Yogyakarta : Graha Ilmu.

Kasim, Muhammad. dkk (2017). Pengaruh Pemberian Pola Makan Sehat Terhadap Status Gizi Anak-anak di TK Bunga Asya: Jurnal Scientific Pinisi, Volume 3, Nomor 1, April 201..

Muaris, H. (2006). Bekal Sekolah untuk Anak Balita. Jakarta: Gramedia Pustaka Utama.

Noor, R. M. (2009). Orangtua Bijaksana, Anak Bahagia. Yogyakarta: Kata Hati.

Olvista. (2013). Keterampilan Berbahasa. Jakarta: Raja Garfindo Persada.

Santoso, S., \& Ranti, A. L. (2014). Kesehatan dan Gizi. Jakarta: Rineka Cipta.

Setiono, Kusdwiratri. 2011. Psikologi Keluarga. Bandung: P. T. Alumni.

Shim, J.E., Juhee,K., Rose, A.M. 2011. Associations of Infant Feeding Practices and Picky Eating Behaviors of Preschool Children. Journal of the American Dietetic Association.111, (9), 1363-1368.

Tovar A, Hennessy E, Pirie A, Must A, Gute DM, Hyatt RR, Kamins CL, Hughes SO. 2012. Feeding styles and child weight status among recent immigrant mother-child dyads. 